\title{
Comparison of The Winters' Seasonality Exponential Smoothing Method With The Pegels' Classification: Forecasting of Turkey's Economic Growth Rates
}

\section{Wınters'ın Mevsimlik Üstel Düzeltme Tahmin Tekniği ve Pegels'in Sınıflandırmasının Karşılaştırılması: Türkiye'nin Ekonomik Büyüme Oranlarının Tahmini}

\section{Dr. Öğretim Üyesi Ibrahim Orkun Oral ${ }^{1}$}

Başvuru Tarihi: 05.05.2019

Kabul Tarihi: 13.09.2019

\begin{abstract}
Being one of the macroeconomic indicators, economic growth is a significant indicator, which shows development level of countries and welfare level of people living within the border of a country. Economic growth has a great importance especially for policy makers. Therefore, forecasting economic growth of a country is of vital importance in taking decisions such as longterm investment, employment etc. and developing, regulating and revising the policies of countries. The study aims to compare the selected exponential smoothing methods used in forecasting of Turkey's economic growth indicators and determine the most appropriate technique. To this end, economic growth rate of Turkey between 1998 and the second quarter of 2018 was addressed and economic growth rate for the third and fourth quarters of 2018 was forecasted depending on the economic growth rate in the second quarter of 2018. Forecasts were carried out by using Winters' seasonality exponential smoothing method based on the characteristics of time series and model selection criteria and additive Holt-Winters' seasonality exponential smoothing method in the Cell B-2 of Pegels' classification. It has been found out that the most appropriate method for the relevant forecasts is the additive Holt-Winters' seasonality exponential smoothing method. It has been concluded that there would be 11,995\% increase in the third quarter and 6,415\% increase in the fourth quarter depending on the economic growth rate in the second quarter of 2018.
\end{abstract}

Keywords: Economic Growth, Forecast, Exponential Smoothing Methods, Economic Growth Forecast

$\ddot{O} z$

Makroekonomik göstergelerden birisi olan ekonomik büyüme, ülkelerin gelişme düzeylerini ve ülke sınırlarında yaşayan insanların refah seviyesini gösteren önemli bir göstergedir. Ekonomik büyüme, özellikle politika yapıcılar açısından çok büyük bir öneme sahiptir. Bu sebeple, bir

\footnotetext{
${ }^{1}$ Ardahan Üniversitesi Faculty of Economics and Administrative Sciences, ibrahimorkunoral@ardahan.edu.tr, ORCID: 0000-0002-1949-6355
} 
ülkenin ekonomik büyüme oranının tahmin edilmesi, uzun dönemli yatırm, istihdam vb. kararların verilmesinde ve ülkelerin politikaların geliștirmesinde, düzenlemesinde, revize etmesinde oldukça büyük bir önem arz etmektedir. Çalş̧mada, Türkiye’nin ekonomik büyüme göstergesinin tahmin edilmesinde üstel düzeltme tahmin teknikleri içerisinden seçilen tekniklerin karşılaşttrılması ve en uygun tekniğin belirlenmesi amaçlanmaktadır. Bu amaç kapsamında, Türkiye’nin 1998 ile 2018 ikinci çeyrek arasındaki ekonomik büyüme oranları ele alnarak 2018 ikinci çeyrek dönemindeki ekonomik büyüme oranına göre 2018 üçüncü ve 2018 dördüncü çeyrek dönemlerine ait ekonomik büyüme oranları tahmin edilmiştir. Zaman serisi özelliklerine ve model seçme kriterlerine göre Winters'in mevsimlik üstel düzeltme tahmin tekniği ve Pegels'in sinflandırmasinda B-2 hücresinde yer alan toplaml Holt-Winters mevsimlik üstel düzeltme tahmin tekniği kullanılarak tahminler gerçekleştirilmiştir. İlgili tahminler için en uygun tekniğin toplaml Holt-Winters mevsimlik üstel düzeltme tahmin tekniği olduğu görülmüştür. Türkiye’nin ekonomik büyüme oraninda 2018 ikinci çeyrek dönemine göre 2018 üçüncü çeyrek döneminde \%11,995 ve 2018 dördüncü çeyrek döneminde ise \%6,415 artış yaşanabileceğ $i$ sonucuna ulaşılmıştır.

Keywords: Ekonomik Büyüme, Tahmin, Üstel Düzeltme Teknikleri, Ekonomik Büyüme Tahmini

\section{Introduction}

Since the beginning of human history, forecasts have always been an issue of concern in every field. Trying to forecast the future and focusing on making decisions based on these forecasts are one of the basic operations in the science as in every sphere of life. Forecasts tried to be performed through different means and methods have been addressed in a more scientific and rational way with the development of technology. It is same in the Economics. Many economic phenomena, indicators, values etc. are tried to be forecasted and road map is prepared depending on the forecasts achieved.

Since the $14^{\text {th }}$ century when the science started to develop, many different techniques for forecasting have been proposed and used. There are a lot of econometric model (such as autoregressive model, moving average method, Box-Jenkins method etc.) in literature to forecast economic data. However, operations such as transformation, data aggregation and aggregation etc. are needed to be applied on the data used in many models. Exponential smoothing methods and the Pegels' classification enable to make forecasts based on the trends and seasonality characteristics of time series data addressed without making any operation on the data.

Being one of the concepts among macroeconomic indicators and showing the welfare level of people living within the border of the country, the concept of economic growth is quite significant for policy makers, investors and the other countries. Thus, wide range of techniques were proposed for the forecast of economic growth. 
In the study, it is aimed to identify the most appropriate exponential smoothing method in forecasting economic growth indicator of Turkey and forecast at which direction and at what rate economic growth rates in the third and fourth quarter of 2018 may change in proportion to economic growth rate in the second quarter of 2018. The study examines the exponential smoothing methods, since these methods do not require any changes on time series data, enable to model trend and seasonality effects in time series and have simpler calculations compared to the other techniques.

In the first part of the study, brief information is given on the concept of economic growth, after addressing past studies in literature. In the second part, model selection criteria for forecasting methods, the Winters' seasonality exponential smoothing method and the Pegels' classification are addressed. In the application part, rates of change of current prices between 1999 and 2018 (second quarter) in Turkey and of economic growth rates are examined compared to the previous periods. After identifying trend and seasonality features of the data obtained from Turkish Statistical Institute (TURKSTAT) database, forecasts have been carried out with the use of appropriate techniques based on the Winters' seasonality exponential smoothing method and the Pegels' classification. In the last part, forecasts achieved are evaluated.

\section{Literature Review}

It is possible to come across studies on forecasting of economic growth in literature. Some of the works aimed at forecasting economic growth are briefly outlined below.

In the study conducted by Junoh (2004), it was aimed to make comparison between artificial neural networks and regression model for growth prediction by using growth indicator data between 1995 and 2000 in Malaysia. Time series data were used for comparison and predictions were made for the period between 1997 and 2000. Li, Liu and Zhao (2007) submitted genetic programming method in order to forecast Gross Domestic Product (GDP) between 2007-2020 by using the GDP values of China, America and Japan between the years of 1980 and 2006. In the study conducted by Samimi, Shirazi and Fazlollahtabar (2007), it was aimed to forecast 8 quarterly periods between 2004 and 2005 by using the GDP values of quarterly periods between 1998-2003 in Iran. Exponential smoothing method and artificial neural networks approaches were used in accordance with the purpose of the study. Mirhagberi (2010) aimed at making comparisons between fuzzy logic and fuzzy artificial neural network methods in order to predict Iran's economic growth situation and accordingly identifying proper forecasting method. To this end, growth values between the years of 1959 and 2006 were evaluated and predictions were made for 2002 and 2006 with the use of both methods. Hussain and Nazir (2013) aimed at analysing the distribution of growth rate of Pakistan during different regimes based on Gini coefficient and forecasting growth rates in agriculture, industry and service sectors and the GDP rate of Pakistan. They forecasted values for 2012 through moving average and exponential smoothing methods by using observation values from 1956 to 2011. The study of Dong and Zhu (2014) aimed to forecast the GDP for eight autonomous regions in Yunnan State of China. Exponential smoothing method and corrected exponential smoothing method were comparatively used for the forecast. Zakai (2014) aimed to forecast the GDP values between the 
years of 2013 and 2025 by using annual GDP values between 1953 and 2012 in Pakistan. He used the ARIMA $(1,1,0)$ model in the application part. Söyler and Kizılkaya (2015) aimed to forecast the GDP as an economic growth variable with the help of artificial neural networks model. In the study, data between the first quarter of 1988 and the third quarter of 2013 were used and forecasts were made for the fourth quarter of 2013 and the fourth quarter of 2014 . Dritsaki (2015) aimed at modelling and forecasting real growth rates of Greece. He used growth rates between the years of 1980 and 2013 through the Box-Jenkins approach and forecasted real growth rates of 2015, 2016 and 2017 with the use of the ARIMA $(1,1,1)$.

Some of the studies where exponential smoothing method was used in forecasting of economic indicators and variables, are presented below. Valakevicius and Brazenas (2015) forecasted the Euro/Dollar parity in their study by using additive Holt-Winters, multiplicative Holt-Winters, reduced additive Holt-Winters and reduced multiplicative Holt-Winters methods. In the analysis, they addressed hourly Euro/Dollar parity data between the periods of 31 January 2009 and 24 December 2012. The best method, which showed success in forecast, was tested as multiplicative HW method in the analysis. The study conducted by Braimllari and Sala (2016) aimed at forecasting monthly food import values between November 2016 - April 2017 through additive Holt-Winters method and seasonality ARIMA (SARIMa) method based on the monthly food import data between January 2005 - October 2016 in Albania. As a result of the analysis, it was indicated that additive Holt-Winters method showed more appropriate results compared to the SARIMA method. Export volume of Turkey was forecasted through the HoltWinters and the Box-Jenkins method in the study of Temuçin and Temiz (2016) and these methods were compared under several evaluation criteria in terms of results they presented. It was stated that the most appropriate results were obtained with the additive Holt-Winters exponential smoothing method among 2014 forecast values calculated by applying the method on 1969-2013 Turkey's export volume data. In the study carried out by Unnikrishnan and Suresh (2016), India's gold imports were forecasted through the ARIMA and linear HoltWinters methods by using daily gold price data of the period between March 2011 and March 2016. In the analysis, it was tested that the ARIMA method was much better in forecasting compared to the Holt-Winters method. Yıldırım and Başeğmez (2017) made predictions with the help of moving averages, the Holt's linear smoothing method, additive Holt-Winters exponential smoothing method, exponential smoothing method with an adaptive response rate by using data on unemployment rate of Turkey from 1996 to 2015. As a result of the analysis, it was determined that additive Holt-Winters exponential smoothing method had the smallest value of MAPE. Tüzemen and Yıldız (2018) aimed to forecast unemployment rates in Turkey for the ex-ante forecast period of November 2016 - January 2018 by using monthly unemployment rates of ex-post forecast period from November 2016 to January 2018. To this end, additive and multiplicative seasonality Holt-Winters methods were used and additive Holt-Winters method was concluded as more appropriate method. 


\section{Theoretical Framework}

In this part, economic growth, model selection criteria, exponential smoothing methods and the Pegels' classification were addressed.

\section{Economic Growth}

Many approaches were suggested related to the concept of economic growth, which is often studied in economics literature and one of the main goals for both developed and developing countries. There have been differences in policies to be implemented to ensure economic growth based on enhancing public welfare or achieve growth throughout historical process.

Defending the ultimate wealth stemmed from metal assets such as gold or silver, Mercantilist approach promoted that precious minerals were the source of economic growth, and population growth would positively affect growth by increasing demand. Arguing against the Mercantilist approach in $18^{\text {th }}$ century, Physiocrats stated that growth was mainly derived from agriculture and increasing production based on agriculture would provide growth by adding value.

Adam Smith explained the source of economic growth based on division of labour and specialisation. Also, he emphasised that specialisation would increase labour productivity with technological progress. Malthus, who brought a different approach to economic growth, explained growth depending on population and food production. He indicated that population and food were not increasing at similar proportion and emphasised population increased quicker compared to food. Considering innovation and technology as the basic foundation of growth, Schumpeter stated that technological progress achieved by the promotion of inventions and innovations was an endogenous variable.

After 1929 crisis, starting to discuss classical theory and focusing on studies related to crisis resulted in emergence of new approaches on the source of economic growth. Keynes, who supported the idea that economy was related to underemployment and increase in investments would have positive effect on growth, suggested demand-side policies as the source of growth. Harrod-Domar, who moved short term macroeconomic model suggested by Keynes to long term, showed the source of economic growth as investments and included population growth, savings and technological progress (Parasiz, 2008, p. 47). One of the pioneer of neo-classical theory, Solow (1994) analysed economic growth in a model, including the variables of increase in capital stock and labour force and technological development. He also stated that main source of economic growth was technological progress accepted as exogenous (Atamtürk, 2007, p. 91). Besides, Mankiw, Romer and Weil (1992) indicated that increasing population rate and fixed capital stock would be merged within improved Solow's model. Apart from neoclassical supporters, Romer (1986), who proposed capital composed of not only physical capital but also human capital, defended growth was based on endogenous factors. Also, Romer (1994), Rebelo (1991), Lucas (1988) and Young (1991) stated that information had a central role in production process in their endogenous growth models. In this context, Becker, Murphy and Tamura (1990) concluded that human capital stock and population growth had an effect on economic growth. Similarly, Grosman and Helpman (1994) indicated that sustainable economic growth was based on endogenous factors such as human capital, population, public expenditure level 
and protection of patent rights. Depending on Arrow's (1962) idea of producing more quality production with lower cost, Grossman and Helpman (1991), Aghion and Howit (1998) suggested the R\&D as the source of sustainable growth.

In addition to the changes occurring in the identification of the source of growth during historical process, making the explanation of the concept of good growth through bad growth brought a new point of view in the United Nations (UN) Human Development Report (1996) (Berber, 2007, p. 6). In this context, types of growth may be listed as growth not preventing unemployment, growth not securing fair income, growth not enhancing individual rights, growth causing social degeneration and growth jeopardising environment and the future of world (Üzümcü, 2015, p. 9). Economic growth graph of Turkey's economy, which undergone periods of change such as the first industrialization period, development plans period, export oriented growth with the Decisions of January 24, 1994 stability measures, 2001 transition to the strong economy program and 2018 new economy program since the proclamation of the Republic, is given figure 1 :

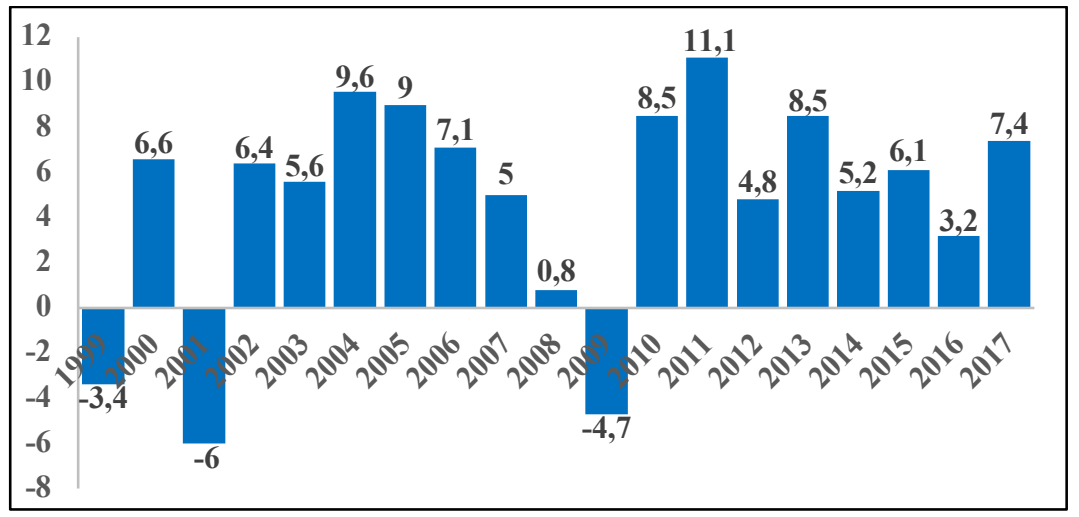

Figure 1. Turkey's 1999-2018 Annual GDP Rates Compared to the Previous Year

Examining the Figure 1, economic growth rates of Turkey fall depending on the economic crisis experienced in 1999, 2001 and 2009 and show floating trend in the other years.

\section{Model Selection Criteria}

There are several model selection criteria in the addressed time series in order to measure the degree of accuracy of forecasting methods used for the future forecasts. Among these, most preferred are mean absolute error-MAD, mean squared error-MSE, mean absolute percentage error-MAPE, mean percentage error-MPE and the Theil's U statistic criteria.

Equations used in the calculation of the MAD, MSE, MAPE and MPE selection criteria are given below respectively (Montgomery, 2015, p. 65). 


$$
\begin{aligned}
& \text { MAD }=\frac{\sum\left|e_{t}\right|}{n} \\
& \text { MSE }=\frac{\sum e_{t}^{2}}{n} \\
& \text { MPE }=\frac{\sum \frac{e_{t}}{Y_{t}}}{n} \\
& \text { MAPE }=\frac{\sum \frac{e_{t} \mid}{Y_{t}}}{\text { MASE }=\frac{\sum\left|e_{t}\right|}{\frac{n}{n-1} \sum_{t=2}^{n}\left|Y_{t}-Y_{t-1}\right|}}
\end{aligned}
$$

Given in the equation No $1 ; \mathrm{e}_{\mathrm{t}}$ refers error term; $\mathrm{n}$ is for number of observation in time series and $\mathrm{Y}_{\mathrm{t}}$ for observation value in the period of $\mathrm{t}$. In general, it is ideal that four criteria should be minimum. The most frequently used criteria among these is the MAPE criterion, which is expressed with a certain percentage, thus, can be used to comment by itself. However, in the study conducted by Makridakis and Hibon (2000), it is stated that using symmetric mean absolute percentage error -sMAPE criterion is more appropriate to use in the event that there is zero or positive values very close to zero. Hyndman and Koehler (2006) suggested mean absolute scaled error-MASE criteria in the event that there were negative observation values in time series.

The Theil's U statistic is both very simple for measurement and practical, since it focuses on the square of errors in order to concentrate on high-value errors rather than low-value errors. Mathematical representation of the Theil's U statistic is as follows (Makridakis et al., 1998, p. 48).

$$
\begin{gathered}
U=\sqrt{\frac{\sum_{t=1}^{n-1}\left(F P E_{t+1}-A P E_{t+1}\right)^{2}}{\sum_{t=1}^{n-1}\left(A P E_{t+1}\right)^{2}}} \\
F P E_{t+1}=\frac{F_{t+1}-Y_{t}}{Y_{t}} \quad A P E_{t+1}=\frac{Y_{t+1}-Y_{t}}{Y_{t}}
\end{gathered}
$$

In the above-mentioned equations $\mathrm{FPE}_{\mathrm{t}+1}$ : represents relative variation of estimation value in the period of $t+1$, and $A P E_{t+1}$ means relative variation of observation value in the period of $t+1$. Being possibly less than 1 increases forecast method's appropriateness and accuracy.

\section{Exponential Smoothing Methods}

Exponential smoothing methods generally mean exponentially decreasing weights, which give lower weight when past data are examined. The basis of these methods can be explained as the last period values have more weight compared to the past periods (Makridakis et al., 1998, 
p.147). Depending on this basic approach, exponential smoothing methods are extended based on trends and seasonality characteristics of time series (Bergmeir et al., 2016, p. 304). Popularity of exponential smoothing methods has been continuing for 50 years due to the fact that they require lower data storage and are simple in application. Also, considering the characteristics (such as variations and fluctuations) in time series and their capability to adapt to these characteristics are among the reasons to be preferred (Goodwin, 2010, p. 30).

There are different exponential smoothing methods by existence of time series components in literature. Different exponential smoothing methods have been developed based on the existence of trend component and seasonality effects or including both components. Within this study, the Winters' seasonality exponential smoothing method is addressed in accordance with the characteristics of time series discussed.

\section{Winters' Seasonality Exponential Smoothing Method}

Winters (1960) indicated that it was possible to develop a model for time series composing of seasonality or quarterly data including proportional, additive or linear trend. He suggested this method with the help of below-mentioned equations.

$$
\begin{aligned}
& \widetilde{\mathrm{S}}_{\mathrm{t}}=\alpha \frac{\mathrm{S}_{\mathrm{t}}}{\mathrm{F}_{\mathrm{t}-\mathrm{L}}}+(1-\alpha)\left(\widetilde{\mathrm{S}}_{\mathrm{t}-1}+\mathrm{R}_{\mathrm{t}-1}\right) \\
& \mathrm{F}_{\mathrm{t}}=\beta \frac{\mathrm{S}_{\mathrm{t}}}{\widetilde{\mathrm{S}}_{\mathrm{t}}}+(1-\beta) \mathrm{F}_{\mathrm{t}-\mathrm{L}} \\
& \mathrm{R}_{\mathrm{t}}=\gamma\left(\widetilde{\mathrm{S}}_{\mathrm{t}}-\widetilde{\mathrm{S}}_{\mathrm{t}-1}\right)+(1-\gamma) \mathrm{R}_{\mathrm{t}-1}
\end{aligned}
$$

In the equations $\widetilde{\mathrm{S}}_{\mathrm{t}}$ is trend constant for the period of $\mathrm{t}$; $\mathrm{L}$ is the length of season (if the data are annual, it is 12 ; if they are quarterly, it is 4 ); $R_{t}$ represents trend slope for the period of $t$; $S_{t}$ represents observation value for the period of $t ; F_{t}$ is seasonality correction factor for the period of $t$; in $0 \leq \alpha \leq 1, \alpha$ is smoothing constant of the model; in $0 \leq \beta \leq 1, \beta$ is seasonality smoothing constant; in $0 \leq \gamma \leq 1, \gamma$ is trend smoothing constant. Initial values for $\widetilde{\mathrm{S}}_{t}$ and $\mathrm{R}_{\mathrm{t}}$ can be determined through the trend line calculated with the functions such as linear, exponential, logarithmic etc. used in the identification of trend. Initial value for $F_{t}$ can be calculated by average of the relevant period of observation values. Values for $\alpha, \beta$ and $\gamma$ can be optimised in a way to make one or more than one model selection criteria minimum. In the event that above mentioned equations are achieved, forecast equation is as follows.

$$
\mathrm{S}_{\mathrm{t}, \mathrm{T}}=\left[\tilde{\mathrm{S}}_{\mathrm{t}}+\mathrm{TR}_{\mathrm{t}}\right] \mathrm{F}_{\mathrm{t}-\mathrm{L}+\mathrm{T}}
$$

T, given above, shows the number of periods to be forecasted.

\section{Pegels' Classification}

Pegels (1969) developed basic exponential smoothing methods depending on some different characteristics. However, he emphasised that these extensions had easy and flexible characteristics to address different forecasting models. 
Pegels suggested nine forecast equations in total by three different trend components and three different seasonality components. Table 1 below summarises the classification.

Table 1. Pegels' Classification

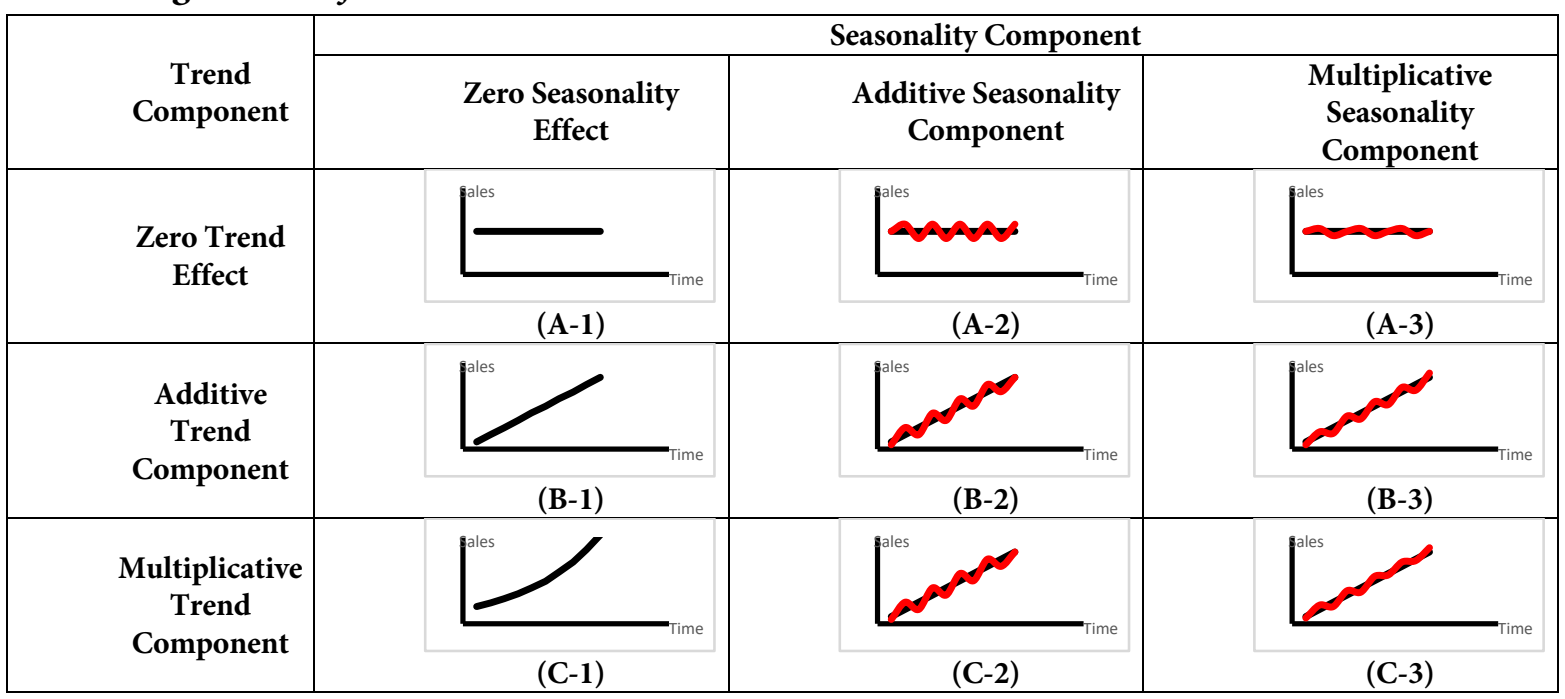

Examining the table above, all the cells are named based on the characteristics of trend and seasonality components For instance, the Cell A-1 shows simple exponential smoothing method, while the Cells B-2 and B-3 are presented as additive or multiplicative Holt-Winters exponential smoothing method depending on the characteristic of seasonality component (Makridakis et al., 1998, p. 170).

There are three primary equation to calculate each classifications. These can be expressed as follows $\mathrm{L}_{\mathrm{t}}$; basic, $\mathrm{b}_{\mathrm{t}}$; trend and $\mathrm{S}_{\mathrm{t}}$ seasonality equations.

$$
\begin{aligned}
& \mathrm{L}_{\mathrm{t}}=\alpha \mathrm{P}_{\mathrm{t}}+(1-\alpha) \mathrm{Q}_{\mathrm{t}} \\
& \mathrm{b}_{\mathrm{t}}=\beta \mathrm{R}_{\mathrm{t}}+(1-\beta) \mathrm{b}_{\mathrm{t}-1} \\
& \mathrm{~S}_{\mathrm{t}}=\gamma \mathrm{T}_{\mathrm{t}}+(1-\gamma) \mathrm{S}_{\mathrm{t}-\mathrm{s}}
\end{aligned}
$$

The equation Number 6 is used except for the situations where times series consist of multiplicative trend and multiplicative seasonality component. Equations given below are used in time series, which consist multiplicative trend and multiplicative seasonality component (Cell C-3).

$$
\begin{aligned}
& \mathrm{L}_{\mathrm{t}}=\alpha \frac{\mathrm{Y}_{\mathrm{t}}}{\mathrm{S}_{\mathrm{t}-\mathrm{s}}}+(1-\alpha)\left(\mathrm{Q}_{\mathrm{t}}^{*} \mathrm{~b}_{\mathrm{t}-1}\right) \\
& \mathrm{b}_{\mathrm{t}}=\beta \frac{\mathrm{L}_{\mathrm{t}}}{\mathrm{L}_{\mathrm{t}-1}}+(1-\beta) \mathrm{b}_{\mathrm{t}-1} \\
& \mathrm{~S}_{\mathrm{t}}=\gamma \frac{\mathrm{Y}_{\mathrm{t}}}{\mathrm{L}_{\mathrm{t}}}+(1-\gamma) \mathrm{S}_{\mathrm{t}-\mathrm{s}}
\end{aligned}
$$

Similarly in all exponential smoothing methods, it is very significant to specify initial values of $\mathrm{L}_{\mathrm{t}}, \mathrm{b}_{\mathrm{t}}$ and $\mathrm{S}_{\mathrm{t}}$ parameters. In the time series with additive seasonality component, initial values 
of related parameters are calculated with the help of below-mentioned equations (Makridakis et al., 1998, p. 168).

$$
\begin{aligned}
& \mathrm{L}_{\mathrm{s}}=\frac{1}{\mathrm{~s}}\left(\mathrm{Y}_{1}+\mathrm{Y}_{2}+\ldots \ldots+\mathrm{Y}_{\mathrm{s}}\right) \\
& \mathrm{b}_{\mathrm{s}}=\frac{1}{\mathrm{~s}}\left[\frac{\mathrm{Y}_{\mathrm{s}+1}-\mathrm{Y}_{1}}{\mathrm{~s}}+\frac{\mathrm{Y}_{\mathrm{s}+2}-\mathrm{Y}_{2}}{\mathrm{~s}}+\ldots \ldots \ldots+\frac{\mathrm{Y}_{\mathrm{s}+\mathrm{s}}-\mathrm{Y}_{\mathrm{s}}}{\mathrm{s}}\right] \\
& \mathrm{S}_{1}=\mathrm{Y}_{1}-\mathrm{L}_{\mathrm{s}}, \mathrm{S}_{2}=\mathrm{Y}_{2}-\mathrm{L}_{\mathrm{s}}, \ldots \ldots \ldots \ldots \mathrm{S}_{\mathrm{s}}=\mathrm{Y}_{\mathrm{s}}-\mathrm{L}_{\mathrm{s}}
\end{aligned}
$$

In the time series with multiplicative seasonality component, on the other hand, initial values for $L_{t}$ and $b_{t}$ are the same with the time series with additive seasonality component while the calculation of $\mathrm{S}_{\mathrm{t}}$, only showing seasonality equation, is made with the below-presented equation.

$$
\mathrm{S}_{1}=\frac{\mathrm{Y}_{1}}{\mathrm{~L}_{\mathrm{s}}}, \mathrm{S}_{2}=\frac{\mathrm{Y}_{2}}{\mathrm{~L}_{\mathrm{s}}}, \ldots \ldots \ldots, \mathrm{S}_{\mathrm{s}}=\frac{\mathrm{Y}_{\mathrm{s}}}{\mathrm{L}_{\mathrm{s}}}
$$

In the equation above, $\mathrm{S}$ shows the length of season (if time series data are monthly, it is 12; if

\begin{tabular}{|c|c|c|c|}
\hline \multirow[b]{2}{*}{$\begin{array}{l}\text { Trend } \\
\text { Component }\end{array}$} & \multicolumn{3}{|c|}{ Seasonality Component } \\
\hline & $\begin{array}{l}\text { Zero } \\
\text { Seasonality } \\
\text { Effect }\end{array}$ & $\begin{array}{l}\text { Additive Seasonality } \\
\text { Component }\end{array}$ & $\begin{array}{l}\text { Multiplicative } \\
\text { Seasonality } \\
\text { Component }\end{array}$ \\
\hline $\begin{array}{l}\text { Zero Trend } \\
\text { Effect }\end{array}$ & $\begin{array}{l}\mathrm{P}_{\mathrm{t}}=\mathrm{Y}_{1} \\
\mathrm{Q}_{\mathrm{t}}=\mathrm{L}_{\mathrm{t}-1} \\
\mathrm{~F}_{\mathrm{t}+\mathrm{m}}=\mathrm{I}_{\mathrm{t}}\end{array}$ & $\begin{array}{l}\mathrm{P}_{\mathrm{t}}=\mathrm{Y}_{\mathrm{t}}-\mathrm{S}_{\mathrm{t}-\mathrm{s}} \\
\mathrm{Q}_{\mathrm{t}}=\mathrm{L}_{\mathrm{t}-1} \mathrm{I}_{\mathrm{t}}=\mathrm{Y}_{\mathrm{t}}-\mathrm{I}_{\mathrm{t}} \\
\mathrm{F}_{\mathrm{t}+\mathrm{m}}=\mathrm{L}_{\mathrm{t}}+\mathrm{S}_{\mathrm{t}+\mathrm{m}-\mathrm{s}}\end{array}$ & $\begin{array}{l}\mathrm{P}_{\mathrm{t}}={ }_{\mathrm{T}} / \mathrm{S}_{\mathrm{t}-\mathrm{s}} \\
\mathrm{Q}_{\mathrm{t}}=\mathrm{L}_{\mathrm{t}-1} \\
\mathrm{I}_{\mathrm{t}}={ }_{\mathrm{T}} / \mathrm{L}_{\mathrm{t}} \\
\mathrm{F}_{\mathrm{t}+\mathrm{m}}=\mathrm{L}_{\mathrm{t}} \mathrm{S}_{\mathrm{t}+\mathrm{m}-\mathrm{s}}\end{array}$ \\
\hline $\begin{array}{l}\text { Additive } \\
\text { Trend } \\
\text { Component }\end{array}$ & $\begin{array}{l}\mathrm{P}_{\mathrm{t}}=\mathrm{Y}_{1} \\
\mathrm{Q}_{\mathrm{t}}=\mathrm{I}_{\mathrm{t}-1}+\mathrm{b}_{\mathrm{t}-1} \\
\mathrm{R}_{\mathrm{t}}=\mathrm{I}_{\mathrm{t}}+\mathrm{I}_{\mathrm{t}-1} \\
\mathrm{~F}_{\mathrm{t}+\mathrm{m}}=\mathrm{L}_{\mathrm{t}}+\mathrm{mb} \mathrm{b}_{\mathrm{t}}\end{array}$ & $\begin{array}{l}\mathrm{P}_{\mathrm{t}}=\mathrm{Y}_{\mathrm{t}}-\mathrm{S}_{\mathrm{t}-\mathrm{s}} \\
\mathrm{Q}_{\mathrm{t}}=\mathrm{L}_{\mathrm{t}-1}+\mathrm{b}_{\mathrm{t}-1} \\
\mathrm{R}_{\mathrm{t}}=\mathrm{L}_{\mathrm{t}}+\mathrm{L}_{\mathrm{t}-1} \\
\mathrm{~T}_{\mathrm{t}}=\mathrm{Y}_{\mathrm{t}}-\mathrm{L}_{\mathrm{t}} \\
\mathrm{F}_{\mathrm{t}+\mathrm{m}}=\mathrm{L}_{\mathrm{t}}+\mathrm{mb}_{\mathrm{t}}+\mathrm{S}_{\mathrm{t}+\mathrm{m}-\mathrm{s}}\end{array}$ & $\begin{array}{l}\mathrm{P}_{\mathrm{t}}=\mathrm{Y}_{\mathrm{t}} / \mathrm{S}_{\mathrm{t}-\mathrm{s}} \\
\mathrm{Q}_{\mathrm{t}}=\mathrm{L}_{\mathrm{t}-1}+\mathrm{b}_{\mathrm{t}-1} \\
\mathrm{R}_{\mathrm{t}}=\mathrm{L}_{\mathrm{t}}+\mathrm{L}_{\mathrm{t}-1} \\
\mathrm{I}_{\mathrm{t}}=\mathrm{Y}_{\mathrm{t}} / \mathrm{L}_{\mathrm{t}} \\
\mathrm{F}_{\mathrm{t}+\mathrm{m}}=\left(\mathrm{L}_{\mathrm{t}}+\mathrm{mb}_{\mathrm{t}}\right) \mathrm{S}_{\mathrm{t}+\mathrm{m}-\mathrm{s}}\end{array}$ \\
\hline $\begin{array}{l}\text { Multiplicative } \\
\text { Trend } \\
\text { Component }\end{array}$ & $\begin{array}{l}\mathrm{P}_{\mathrm{t}}=\mathrm{Y}_{\mathrm{t}} \\
\mathrm{Q}_{\mathrm{t}}=\mathrm{L}_{\mathrm{t}-1} \mathrm{~b}_{\mathrm{t}-1} \\
\mathrm{R}_{\mathrm{t}}=\mathrm{L}_{\mathrm{t}} / \mathrm{L}_{\mathrm{t}-1} \\
\mathrm{~F}_{\mathrm{t}+\mathrm{m}}=\mathrm{L}_{\mathrm{t}} \mathrm{b}_{\mathrm{t}}^{\mathrm{m}}\end{array}$ & $\begin{array}{l}\mathrm{P}_{\mathrm{t}}=\mathrm{Y}_{\mathrm{t}}-\mathrm{S}_{\mathrm{t}-\mathrm{s}} \\
\mathrm{Q}_{\mathrm{t}}=\mathrm{L}_{\mathrm{t}-1} \mathrm{~b}_{\mathrm{t}-1} \\
\mathrm{R}_{\mathrm{t}}=\mathrm{L}_{\mathrm{t}} / \mathrm{L}_{\mathrm{t}-1} \\
\mathrm{~T}_{\mathrm{t}}=\mathrm{Y}_{\mathrm{t}}-\mathrm{L}_{\mathrm{t}} \\
\mathrm{F}_{\mathrm{t}+\mathrm{m}}=\mathrm{L}_{\mathrm{t}} \mathrm{b}_{\mathrm{t}}^{\mathrm{m}}+\mathrm{S}_{\mathrm{t}+\mathrm{m}-\mathrm{s}}\end{array}$ & $\begin{array}{l}\mathrm{P}_{\mathrm{t}}=\mathrm{Y}_{\mathrm{t}} / \mathrm{S}_{\mathrm{t}-\mathrm{s}} \\
\mathrm{Q}_{\mathrm{t}}=\mathrm{L}_{\mathrm{t}-1} \mathrm{~b}_{\mathrm{t}-1} \\
\mathrm{R}_{\mathrm{t}}=\mathrm{L}_{\mathrm{t}} / \mathrm{L}_{\mathrm{t}-1} \\
\mathrm{~T}_{\mathrm{t}}=\mathrm{Y}_{\mathrm{t}} / \mathrm{L}_{\mathrm{t}} \\
\mathrm{F}_{\mathrm{t}+\mathrm{m}}=\mathrm{L}_{\mathrm{t}} \mathrm{mb} \mathrm{b}_{\mathrm{t}} \mathrm{S}_{\mathrm{t}+\mathrm{m}-\mathrm{s}}\end{array}$ \\
\hline
\end{tabular}
they are quarterly, it is 4). Calculation and forecast equations used in the Pegels' classification are presented in the Table 2.

Table 2. Calculation and Forecast Equations Used in the Pegels' Classification

Source: Makridakis et al., 1998,p. 171.

$s$ in the equations given in the Table 2 represents the length of season (if time series data are monthly, it is 12 ; if they are quarterly, it is 4 ) and $\mathrm{m}$ is the number of periods to be forecasted. 


\section{Purpose of the Study and Data Sets Used}

In the study, it is aimed to identify the most appropriate exponential smoothing method to be used in forecasting of Turkey's economic growth indicators. With this purpose, exponential smoothing methods and the Pegels' classification were used in forecasts. The reason why these methods were used is that they do not require any changes on time series data addressed; enable to model trend and seasonality effects in the time series and have simpler calculations compared to the other techniques. Within the scope of this purpose, Turkey's quarterly economic growth rates between the years of 1998 and the second quarter of 2018 have been addressed and appropriate exponential smoothing methods have been identified depending on the characteristics of time series. In the second step, Turkey's economic growth rates in the third and fourth quarters of 2018 have been forecasted in comparison with the economic growth rates in the second quarter of 2018 through the identified methods. The quarterly data between the years 1998 and the second quarter of 2018 received from the Turkish Statistical Institute (TURKSTAT) have been used in the study. The reason why the year of 1998 was chosen as the oldest date is that the oldest data in the TURKSTAT database are current prices and the GDP rates of the period of the first quarter of 1998. Since the difference compared to the previous period is taken as the basis,

$$
Y_{t}=\left(\frac{Y_{t}-Y_{t-1}}{Y_{t-1}}\right) \times 100
$$

rates of change have been calculated through the above-mentioned equation. As a result of this calculation, the value of the first quarter of 1998 is lost. With the aim of equalising the number of all quarterly data, the part of growth data starting from the first quarter of 1999 have been included in the analysis.

\section{Empirical Results}

Preliminary tests and basic analysis results have been presented in detail in accordance with the purpose of the study. Since there are negative values in the time series used, evaluations have been first made based on the MASE criteria in all steps of model identification.

\section{Analyses of Trend and Seasonality Effect}

Prior to the forecasts, it has been examined which exponential smoothing method would be used and whether trend and seasonality effects exist in order to identify which cell will be chosen in the Pegels' classification. In case of the presence of trend and seasonality effects, whether method is appropriate either for additive or multiplicative effects is determined. Rates of change of the economic growth rates of Turkey have been calculated compared to the previous year and unit root test (ADF) have been applied at the first step. As a result of the analysis, the following results have been achieved. 
Table 3. Results of the Unit Root Test

\begin{tabular}{|l|l|l|l|}
\hline \multicolumn{4}{|c|}{ In the Level of Variable } \\
\hline \multicolumn{2}{|c|}{} & t-Statistic & Prob. $^{*}$ \\
\hline Augmented Dickey-Fuller test statistic & -1.859531 & \multirow{2}{*}{0.0603} \\
\hline Test critical values: & $1 \%$ level & -2.597476 & \multirow{2}{*}{} \\
\cline { 2 - 3 } & $5 \%$ level & 1.945389 & \\
\cline { 2 - 3 } & $10 \%$ level & -1.613838 & \\
\hline The State of Variable After the First Differences & \multirow{2}{*}{ Prob. ${ }^{*}$} \\
\hline \multirow{2}{*}{ Augmented Dickey-Fuller test statistic } & t-Statistic & -43.57023 \\
\hline Test critical values: & $1 \%$ level & -2.597476 & \multirow{2}{*}{} \\
\cline { 2 - 3 } & $5 \%$ level & -1.945389 & \\
\cline { 2 - 3 } & $10 \%$ level & -1.613838 & \\
\hline
\end{tabular}

Examining the Table 3, it has been concluded that rate of change of the GDP values are not static in their level compared to the previous year (prob value $>0,005$ ), while the series has become static (prob value $<0,05$ ) after the initial differences. This result shows that the series is not static and consisting unit root. Once the presence of trend is identified, type of the related trend has been determined. Prediction have been made for both additive and multiplicative trend model to determine the type of trend. As a result of the calculations made, values on all model selection criteria have been presented on the Table 4 .

Table 4. Calculations for Determining the Type of Trend

\begin{tabular}{|l|l|l|l|l|l|}
\hline Forecast Method & Trend Function & MAD & MSE & MPE & MASE \\
\hline Additive Model & $9.468-0,0977(\mathrm{t})$ & 5,61 & 36,3 & 0,17 & 0,4 \\
\hline $\begin{array}{l}\text { Multiplicative } \\
\text { Model }\end{array}$ & $5,53-0,0023(\mathrm{t})$ & 8,98 & 108,84 & 0,38 & 0,65 \\
\hline
\end{tabular}

When the Table 5 has been examined, it has been concluded that trend is additive since model selection criteria achieved through the additive trend model give smaller results. A graphics on predictions made based on additive trend model is presented in the Figure 2.

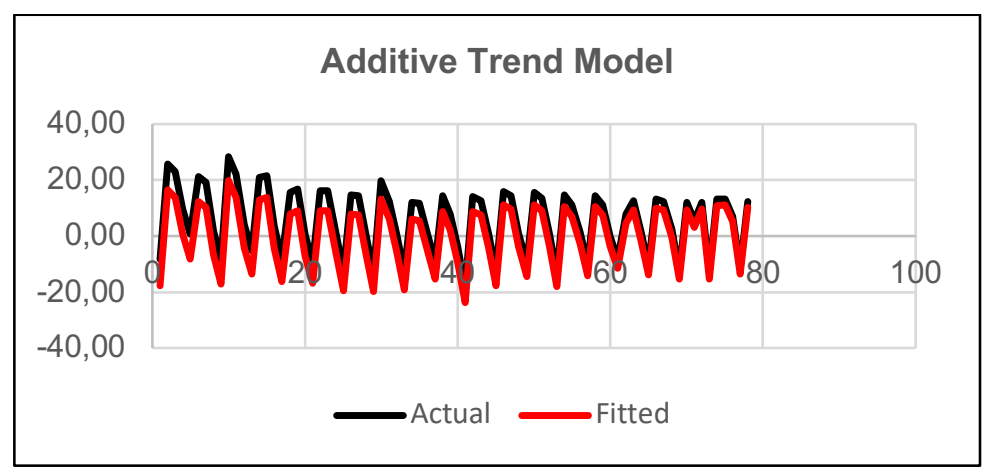

Figure 2. Predictions of Turkey's Quarterly GDP Values between the Years of 1999-2018 by Additive Trend Model 
It is considered that the graph of additive model in the Figure 2 is compatible with the model selection criteria. This means the result obtained is visually compatible with observation values, as well.

Following the identification of presence and type of the trend, seasonality effects are found out. Several methods have been used to search the presence of seasonality effect in time series. The presence of seasonality effect in time series is found out through the descriptive methods such as graphical representations, moving average methods, average percentage methods, season index as well as regression and variance analysis (one way ANOVA) (Ünsal, 1997, p. 121). Accordingly, a correlogram has been formed through autocorrelation analysis by analysing quarterly data between 1999 and the second quarter of 2018. Correlogram achieved is presented on the Figure 3.

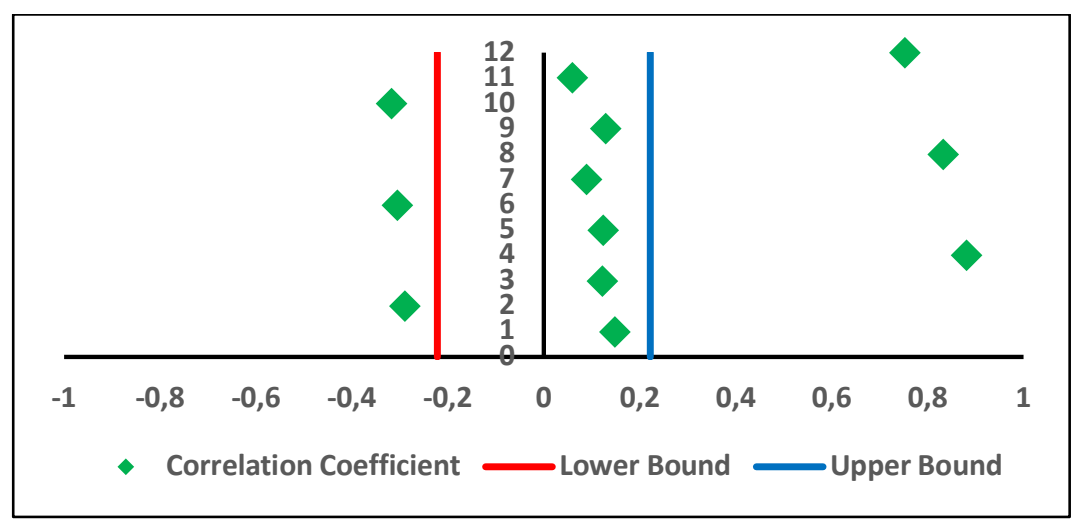

Figure 3. Correlogram on the Autocorrelation Analysis

In the Figure 3, it is possible to comment that seasonality effect exists particularly in the second and fourth quarters in accordance with the correlogram achieved through the autocorrelation analysis. However, significance level has been found as 0,000 in the one-way ANOVA to test the hypothesis suggesting that there is no significant difference between measurements. This result shows there is a seasonality effect and the hypothesis proposed cannot be accepted. The type of seasonality effect should be determined after the presence of seasonality effect. Seasonality components have been calculated for both models as in the identification of the type of trend and predictions have been made.

Table 5. Estimate Seasonality Component of Time Series

\begin{tabular}{|c|c|l|l|l|l|}
\hline Time Series Model & Seasonality Component & MAD & MSE & MPE & MASE \\
\hline \multirow{4}{*}{ Additive Model } & $-15,81$ & & & & \\
& 10,35 & $-0,07$ & 115,47 & $-0,32$ & 0,71 \\
& 9,18 & & & & \\
& $-3,72$ & & & & \\
Multiplicative & $-2,63$ & 10,59 & 145,93 & 0,49 & 0,76 \\
Model & 2,94 & & & & \\
& 0,29 & & & & \\
\hline
\end{tabular}


When the Table 5 has been examined, it has been concluded that seasonality component is additive, since model selection criteria achieved through the additive seasonality component model give smaller results. A graphic on predictions made based on additive seasonality component model is presented in the Figure 4.

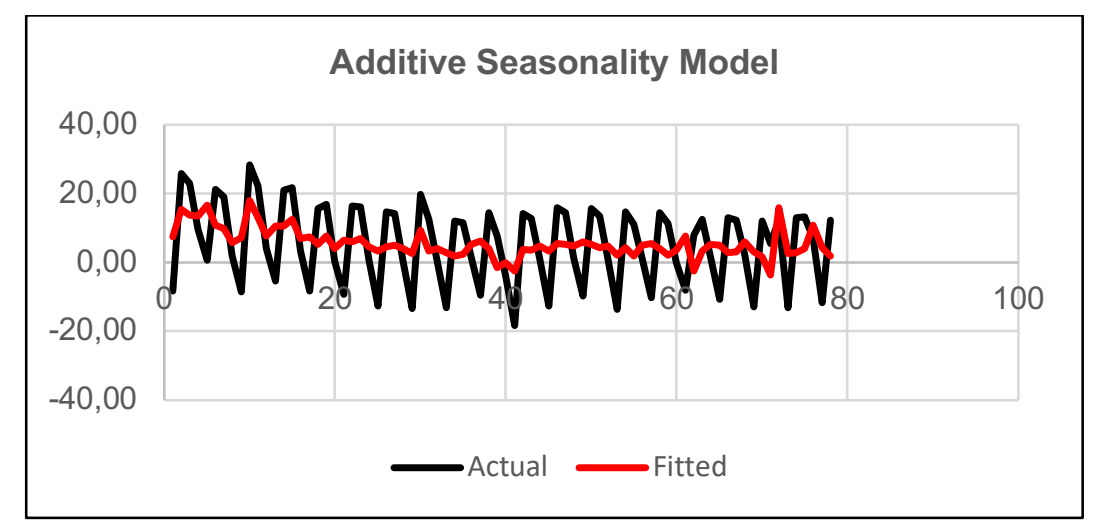

Figure 4. Predictions of Turkey's Quarterly GDP Values between the Years of 1999-2018 by Additive Seasonality Component Model

It is considered that the graph of additive model in the Figure 4 is compatible with the model selection criteria. This means the result obtained is visually compatible with observation values, as well.

\section{Model Selection Criteria of Forecast Methods Used}

After determining the type of trend and seasonality effects of the series addressed, forecasts have been made. In this stage, the Winters' seasonality exponential smoothing method is addressed in accordance with the characteristics of time series. Also, it is concluded that the Cell C-2 is appropriate for the characteristics of the series in the Pegels' classification. Model selection criteria of the forecast methods used are summarised in the Table 6.

Table 6. Values of Model Selection Criteria for the Methods Used for Forecast

\begin{tabular}{|l|l|l|l|l|l|}
\hline Forecast Method & MAD & MSE & MASE & MPE & $\begin{array}{l}\text { Theils's } \\
\text { U }\end{array}$ \\
\hline $\begin{array}{l}\text { Winters' Seasonality } \\
\text { Exponential Smoothing } \\
\text { Method } \\
(\alpha=0,2718 ; \beta=0,384 ; \\
\gamma=0,3637)\end{array}$ & 4,73 & 4,73 & 0,32 & 44,69 & 0,28 \\
\hline $\begin{array}{l}\text { Pegels' Classification (Cell B-2) } \\
(\alpha=0 ; \beta=0,0007 ; \\
\gamma=0,3139)\end{array}$ & 2,33 & 9,93 & 0,16 & 0,37 & 0,46 \\
\hline
\end{tabular}

Coefficients of the methods presented in the Table 6 ( $\alpha, \beta$ and $\gamma$ ) have been obtained with the help of MS Excel Solver in a way to optimise the MASE criteria. Mathematical model, which will optimise the MASE criteria, is obtained as follows. 


$$
\begin{aligned}
& \quad \operatorname{Min} \text { MASE }=\frac{\sum\left|e_{\mathrm{t}}\right|}{\frac{\mathrm{n}}{\mathrm{n}-1} \sum_{\mathrm{t}-2}^{n}\left|\mathrm{Y}_{\mathrm{t}}-\mathrm{Y}_{\mathrm{t}-1}\right|} \\
& \text { s.t. } \\
& 0 \leq \alpha \leq 1 \\
& 0 \leq \beta \leq 1 \\
& 0 \leq \gamma \leq 1
\end{aligned}
$$

Graphics comparing the prediction values achieved through the methods used in the study and actual values are presented in the Figure 5 and Figure 6, respectively.

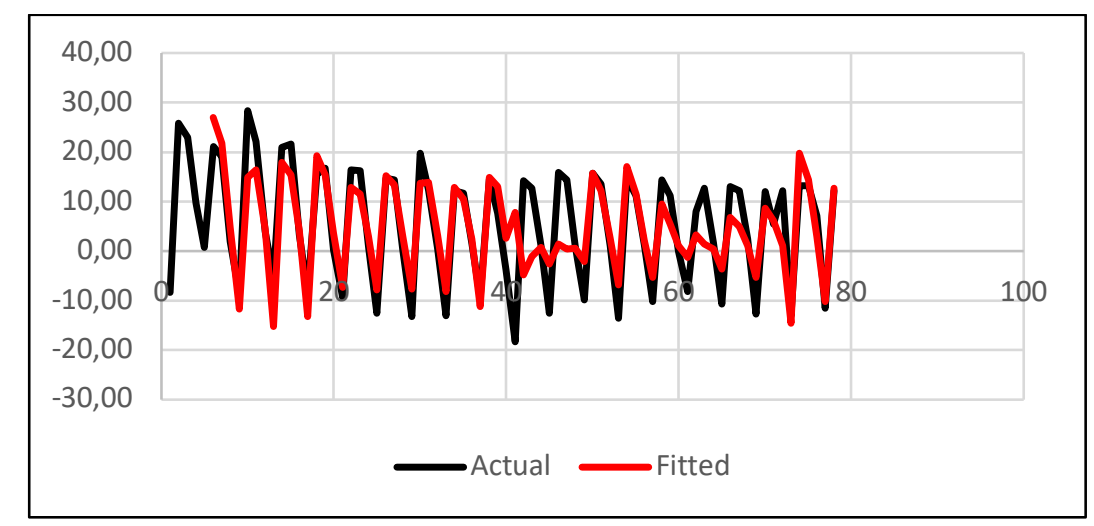

Figure 5. Predictions and Observation Values Obtained Through the Winters' Seasonality Exponential Smoothing Method

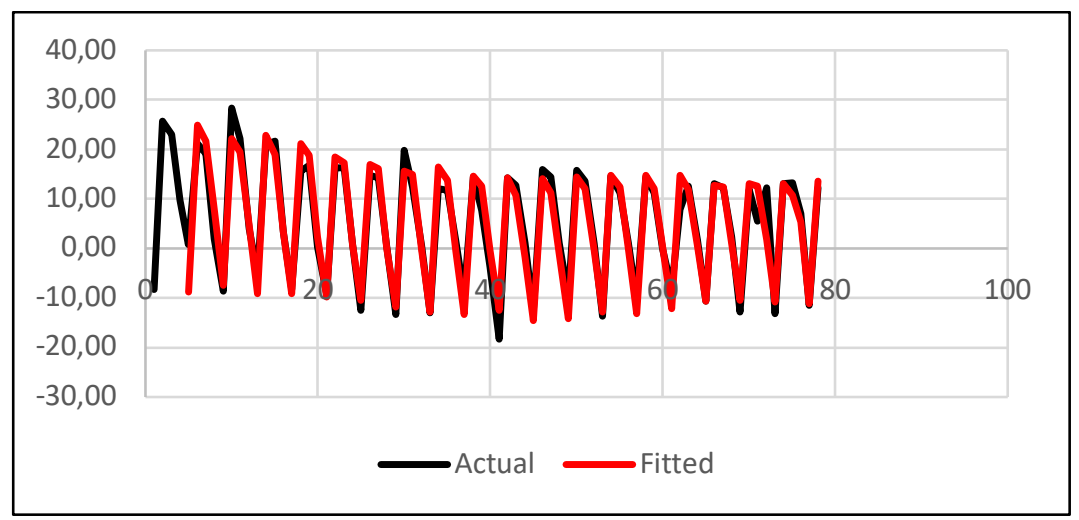

Figure 6. Predictions and Observation Values Obtained Through the Pegels' Classification Cell B-2 (Additive Holt-Winters) Exponential Smoothing Method

It is possible to state that the Cell B-2 in the Pegels' classification gave more appropriate results when graphics comparing model selection, prediction and actual values are evaluated together. Also, all criteria except for MSE criteria have smaller values, which supports the fact that the Holt-Winters' exponential smoothing method gives more compatible results compared to the observation values according to the Winters' exponential smoothing method. It can be seen that prediction values obtained with the Holt-Winters' exponential smoothing method in the Cell B-2 have a better appearance overlapping actual observations. 


\section{Calculated Forecast Values}

Estimated rates of change comparing the values of the third and fourth quarter of 2018 to the actual values in the second quarter of 2018 through the forecast methods in the study are given in the Table 7.

Table 7. Forecast Values for Methods Used

\begin{tabular}{|l|l|l|}
\hline \multirow{2}{*}{ Forecast Method } & \multicolumn{2}{|l|}{ Periods } \\
\cline { 2 - 3 } & 2018-III & 2018-IV \\
\hline $\begin{array}{l}\text { Winters' Seasonality Exponential Smoothing Method } \\
(\alpha=0,2718 ; \beta=0,384 ; \gamma=0,3637)\end{array}$ & 7,995 & 1,931 \\
\hline $\begin{array}{l}\text { Pegels' Classification (Cell B-2) } \\
(\alpha=0 ; \beta=0,0007 ; \gamma=0,3139)\end{array}$ & 11,995 & 6,415 \\
\hline
\end{tabular}

Forecasts in the Cell B-2 preferred according to the Pegels' classification foreseen 7,955\% increase in the third quarter and $1,931 \%$ increase in the fourth quarter in comparison to the second quarter of 2018. According to the Winters' seasonality exponential smoothing method, there is $11,995 \%$ increase in the third quarter and $6,415 \%$ increase in the fourth quarter in the economic growth compared to the second quarter of 2018.

\section{Conclusion}

The study aims to forecast the third and fourth quarter of 2018 depending on the economic growth rate of Turkey in the second quarter of 2018. In this context, the smallest values of the MAD, MSE, MASE and MPE among the exponential smoothing methods and the Theils U statistical criteria are evaluated. Accordingly, the Winters seasonal exponential smoothing method and the Holt-Winters' exponential smoothing methods in the Cell B-2 in the Pegels' Classification have been compared. As a result, it has been concluded that forecasts of the HoltWinters' exponential smoothing methods have more appropriate model identification criteria. The results within the study are compatible with the results of the other studies when they are compared to the studies on economic indicator forecasts through the exponential smoothing methods in literature. The most appropriate method is found out as the additive Holt-Winters' exponential smoothing method in the Cell B-2 of the Pegels' classification according to the studies of Yıldırım and Başeğmez (2017) and Tüzemen and Yıldız (2018) aiming to forecast unemployment rate of Turkey; Temuçin and Temiz (2016) aiming to forecast export rate of Turkey; Braimllari and Sala (2016) planning to forecast food import of Albania. In this context, it can be evaluated that the Holt-Winters exponential smoothing method as the most appropriate method is a compatible result with literature.

Economic growth is an important concept particularly for policy makers in the country, other countries and investors. Policy makers benefit from forecasting of economic growth, while other countries use it for establishing economic cooperation with the relevant country and investors, on the other hand, use it for measuring future production potential of the country. For this reason, economic growth as one of the important economic indicators should be 
forecasted correct and clearly. Therefore, exponential smoothing methods, which are simple for calculation and clear compared to the other methods, consider the trend and seasonality effects of the previous data, are used in the study. As a result of the study, it has been forecasted that Turkey will continue to grow in third quarter of 2018 in comparison to the second quarter. According to the data announced by the TURKSTAT in December, Turkey grew 1,6 percent in the third quarter of 2018. If the study is evaluated with this result, it can be concluded that the forecast is compatible with the actual results. Also, it is possible to state that following the identification of trend and seasonality component characteristics taking into consideration the past values, economic growth can be forecasted with the help of exponential smoothing methods.

Exponential smoothing methods have been examined in the study and forecasts have been made by identifying appropriate methods. Methods such as artificial neural networks, BoxJenkins, ARMA, ARIMA etc. frequently referred in literature can be compared with exponential smoothing methods. Besides, exponential smoothing methods can be used in forecasting of economic indicators such as inflation, savings, domestic debt stock, current account deficit etc. Also, exponential smoothing methods can be applied for forecasting population growth rate directly affecting economic growth and technological development through information techniques development index.

\section{References}

Aghion P. ve Howitt P. (1998). Endogenous Growth Theory. England: The MIT.

Arrow, K.J. (1962). The Economic Implication of Learning by Doing. Review of Economic Studies, 29, 155-173.

Atamtürk, B. (2007). Büyüme Teorileri ve IMF Politikaları. Marmara Üniversitesi İktisadi ve İdari Bilimler Fakültesi Dergisi, 22(1), 89-103.

Becker, G.S., Murphy, K. M. ve Tamura, R. (1990). Human Capital, Fertility and Economic Growth. Journal of Political Economy, 98(5), 12-37.

Berber, M., (2007). İktisadi Büyüme ve Kalkınma, Trabzon: Derya,.

Bergmeir, C., Hyndman, R. J. ve Benitez, J. M. (2016). Bagging Exponential Smoothing Methods Using STL Decomposition and Box-Cox Transformation. International Journal of Forecasting, 32, 303-312.

Braimllari, A. ve Sala, E. (2016). Modeling and Forecasting of Food Imports in Albania. The AlbanianJournal of AgriculturalSciences, 15(4), 200-205. 
Dong, Z. ve Zhu, G. S. (2014). A Modified Exponential Smoothing Model for Forecasting Per Capita GDP in Yunnan Minority Area. Applied Mechanics and Materials, 599(601), 20742078.

Dritsaki, C. (2015). Forecasting Real GDP Rate through Econometric Models: An Empirical Study from Greece. Journal of International Business and Economics, 3(1), 13-19.

Goodwin, P. (2010). The Holt-Winters Approach to Exponential Smoothing: 50 Years Old and Going Strong. Foresight: The International Journal of Applied Forecasting, 19, 30-33.

Grossman,G.M. ve Helpman, E. (1991). Quality Ladders in the Theory of Growth. Review of Economic Studies, 58(1), 43-61.

Grossman,G.M. ve Helpman, E. (1994). Endogenous Innovation in the Theory of Growth. Journal of Economic Perspectives, 8(1), 21-44.

Hussain, A. ve Nazir, N. (2013). Analysis of Growth Rates in Different Regimes of Pakistan: Distribution and Forecasting. Journal of Managerial Sciences, 7(1), 37-57.

Hyndman, R. J. ve Koehler, A. B. (2006). Another Look at Measures of Forecast Accuracy. International Journal of Forecasting, 22, 679-688.

Junoh, M. (2004). Predicting GDP Growth in Malaysia Using Knowledge-Based Economy Indicators: A Comparison Between Neural Network And Econometric Approaches. Sunway College Journal, 1, 39-50.

Li, M., Liu, G. ve Zhao, Y. (2007). Forecasting GDP Growth Using Genetic Programming. Prooceedings of Third International Conference on Natural Computation (ICNC 2007), 2427 Ağustos 2007, Haikou, Çin, 393-397

Lucas, R. (1988). On The Mechanics of Economic Development. Journal of Monetary Economics. 22, 3-42.

Makridakis, S., ve Hibon, M. (2000). The M3-Competition: Results, Conclusions and Implications. . International Journal of Forecasting, 16, 451-476.

Makridakis, S., Wheelwright, S. C. ve Hyndman, R. J. (1998). Forecasting: Methods And Applications. John Wiley \& Sons. Inc, United State of America.

Mankiw, G. N., Romer, D. ve Weil, D. N. (1992). A Contribution to the Empirics of Economic Growth. The Quarterly Journal of Economics, 107(2), 407-437.

Mirbagheri, M. (2010). Fuzzy-Logic and Neural Network Fuzzy Forecasting of Iran GDP Growth. African Journal of Business Management, 4(6), 925-929. 
Montgomery, D. C., Jennings, C. L. ve Kulahci, M. (2015). Introduction to Time Series Analysis and Forecasting. John Wiley \& Sons, Inc, Hoboken.

Parasız, İ. (2008). Ekonomik Büyüme Teorileri., Bursa: Ezgi.

Pegels, C. C. (1969). Exponential Forecasting: Some New Variations. Management Science, $15(5), 311-315$.

Rebelo, S. (1991). Long-Run Policiy Analysis and Long-Run Growth. Journal of Political Economy, 99 (3), 500-521.

Romer, M. P. (1994). The Origins of Endegenous Growth. Journal of Economic Perspectives, $8(1), 3-22$.

Romer, P. (1986). Increasing Returns and Long-Run Growth. Journal of Political Economy, 94, 1002-1037.

Samimi, A. J., Shirazi, B. ve Fazlollahtabar, H. (2007). A Comparison Between Time Series, Exponential Smoothing, and Neural Network Methods to Forecast GDP of Iran. Iranian Economic Review, 12(19), 19-35.

Solow, R. M. (1994). Perspectives on Growth Theory. Journal of Economic Perspectives, 8(1), 45-54.

Söyler, H. ve Kızılkaya, O. (2015). Türkiye'nin GSYİH Tahmini için Yapay Sinir Ağları Model Performanslarının Karşılaştırılması. Celal Bayar Üniversitesi İktisadi ve İdari Bilimler Dergisi, 16(1), 45-58.

Temuçin, T. ve Temiz, İ. (2016). Türkiye Dış Ticaret İhracat Hacminin Projeksiyonu: HoltWinters ve Box, Jenkins Modellerinin Bir Kıyaslaması. Süleyman Demirel Üniversitesi İktisadi ve İdari Bilimler Fakültesi Dergisi, 21 (3), 937-960.

Tüzemen, A. ve Yıldız, Ç. (2018). Holt-Winters Tahminleme Yöntemlerinin Karşılaştırmalı Analizi: Türkiye İsssizlik Oranları Uygulaması. Atatürk Üniversitesi İktisadi ve İdari Bilimler Dergisi, 32(1), 1-18.

Ünsal, A. (1997). Zaman Serilerinde Regresyon ve Varyans Analizi Yöntemleri İle Mevsimsel Dalgalanmaların Araştırılması ve Bir Uygulama. Ekonomik Yaklaşım, 8 (26), pp. 119 130 .

Üzümcü, A. (2015). İktisadi Büyüme. İstanbul: Beta.

Valakevicius, E. ve Brazenas, M. (2015). Application of the Seasonal Holt-Winters Model to Study Exchange Rate Volatility. Inzinerine Ekonomika-Engineering Economics, 26 (4), 384-390. 
Winters, P. R. (1960). Forecasting Sales By Exponentially Weighted Moving Averages. Managment Science, 6(3), $324-342$.

Yıldırım, H. ve Başeğmez, H. (2017). Analysis and Forecast of Turkey Unemployment Rate. Global Journal of Mathematical Analysis, 5(1), 11-15.

Young, A. (1991). Learning by Doing and the Dynamic Effect of International Trade. The Quarterly Journal of Economics, 106(2), 369-405.

Zakai, M. (2014). A Time Series Modeling on GDP of Pakistan. Journal of Contemporary Issues in Business Research, 3(4), 200-2 